\title{
Removal of Aqueous Lead and Copper Ions by Using Natural Hydroxyapatite Powder and Sulphide Precipitation in Cyanidation Process
}

\author{
José Refugio Parga ${ }^{1 *}$, Jesús Leobardo Valenzuela ${ }^{2}$, Víctor Vazquez ${ }^{2}$, Mario Rodriguez ${ }^{1}$, \\ Héctor Moreno ${ }^{3}$ \\ ${ }^{1}$ Department of Metallurgy and Materials Science, Institute Technology of Saltillo, Saltillo, Mexico; ${ }^{2}$ Departament of Chemical En- \\ gineering and Metallurgy, University of Sonora, Hermosillo, Mexico; ${ }^{3}$ Department of Chemistry, Institute Technology of Laguna, \\ Torreon, Mexico. \\ Email: *jrparga@its.mx
}

Received October $18^{\text {th }}, 2012$; revised November $22^{\text {nd }}, 2012$; accepted January $15^{\text {th }}, 2013$

Copyright (C) 2013 José Refugio Parga et al. This is an open access article distributed under the Creative Commons Attribution License, which permits unrestricted use, distribution, and reproduction in any medium, provided the original work is properly cited.

\begin{abstract}
Mining, ore processing, and smelting activities have contaminated soil and water resources with cyanide and heavy metals throughout the world. In-situ chemical immobilization is a remediation technology that decreases the concentrations of dissolved ions of copper cyanide and lead hydroxides by adsorption or precipitation. This study deals, with a process to recover lead hydroxides with natural hydroxyapatite powder and copper cyanide ions with sulphide precipitation from solutions of the cyanidation process. This technology is based on inducing nucleated precipitation of copper and silver in a serpentine reactor, using sodium sulfide as the precipitator, and sulfuric acid for $\mathrm{pH}$ control. Results show that $\mathrm{pH}$ value has a significant effect on copper cyanide removal efficiency, and it was determined the optimal $\mathrm{pH}$ range to be 2.5 - 3. At this $\mathrm{pH}$ value, the copper cyanide removal efficiency achieved was up to $99 \%$ with 60 percent of copper purity and the cyanide ions associated with this complex the recovery was $90 \%$. For the elimination of lead hydroxides ions from the aqueous cyanidation process with natural hydroxiapatite powder the recovery was $99 \%$. The abundance of cow bones, its low price and non-aggressive nature towards the environment are advantages for its utilization in point of view of wastewater cleanup and Dore with higher quality.
\end{abstract}

Keywords: Natural Hydroxyapatite; Sulphide Precipitation; Zinc Cementation

\section{Introduction}

Gold and silver has been considered a precious metal since ancient times, and the search for these precious metals has stimulated world exploration. Early mining was largely by placer methods with a multitude of miners working stream deposits (placers) by various hydraulic techniques. The gold was recovered by gravity separation or by amalgamation with mercury (harmful practice). Cyanidation, a chemical process for gold dissolution, was introduced about 1890 in New Zealand and South Africa. It replaced the chlorination method which had been in use. The cyanidation process as patented by MacArthur et al. involved two steps [1]:

1) Dissolution of gold from ores by an alkali cyanide solution.

2) Recovery or Cementation of gold from the leach

\footnotetext{
${ }^{*}$ Corresponding author.
}

solution by metallic zinc powder.

In 1900, the flotation process, was first used for concentrate fine hydrophobic particles of gold to rising bubbles in a flotation cell and this froth process came into general use in the 1930s. Then, heap leaching, essentially a form of cyanidation treatment, came into general practice for the treatment of low-grade ores in 1970. Later, the hydrometallurgy of gold greatly advanced in the 1973 s with the widespread application of activated carbon technology [2], and aqueous oxidation of gold refractory ores. It is widely accepted that gold dissolution in cyanide solutions occurs as sequence of two reactions shown in Equations (1) and (2). Silver is accomplished in the same fashion.

$$
\begin{aligned}
& \mathrm{Au}+4 \mathrm{NaCN}+\mathrm{O}_{2}+2 \mathrm{H}_{2} \mathrm{O} \rightarrow \\
& 2 \mathrm{Na}\left[\mathrm{Au}(\mathrm{CN})_{2}\right]+2 \mathrm{NaOH}+\mathrm{H}_{2} \mathrm{O}_{2}
\end{aligned}
$$


$2 \mathrm{Au}+4 \mathrm{NaCN}+\mathrm{H}_{2} \mathrm{O}_{2} \rightarrow 2 \mathrm{Na}\left[\mathrm{Au}(\mathrm{CN})_{2}\right]+2 \mathrm{NaOH}(2)$

Elsner's equation shows that oxygen is critical for the dissolution of gold. The stoichiometry of the process shows that 4 moles of cyanide are needed for each mole of oxygen present in solution. At room temperature and standard atmospheric pressure, approximately $8.2 \mathrm{mg}$ of oxygen are present in one liter of water. This corresponds to $0.27 \times 10^{-3} \mathrm{~mol} / \mathrm{L}$. Accordingly, the sodium cyanide concentration (molecular weight of $\mathrm{NaCN}=49$ ) should be equal to $4 \times 0.27 \times 10^{-3} \times 49=0.05 \mathrm{~g} / \mathrm{L}$ or approximately $0.01 \%$. This was confirmed in practice at room temperature by a very dilute solution of $\mathrm{NaCN}$ of $0.01 \%$ $-0.5 \%$ for ores, and for concentrates rich in gold and silver of $0.5 \%-5 \%$ [3]. Also, lime is added to keep the system at an alkaline $\mathrm{pH}$ of $10.5-11.0$. This protective alkalinity is required to counteract the generation of acid during cyanidation, thereby preventing cyanide degradation and the formation of deadly HCN gas.

Other factors affecting gold leaching kinetics are grain size, agitation speed, temperature, pressure, sulphide ions, cyanicides and preg-robbing. In the cyanidation process is always necessary to bleed some of the leach solution to maintain a tolerable level of impurities ions like copper and lead since the bulk of the cyanide solution is recycled. The bleed solution, however, is poisonous and must be destroyed before disposal in the environment. Thus, the cyanide present in either form has a high degree of toxicity that needs treatment. In normal conditions, cyanide can be reduced by natural degradation mechanisms, by means of exposure of the cyanide solution to solar radiation in large settling ponds or cyanide removal by volatilization of free cyanide. Since the natural degradation process needs proper climatic conditions to be efficient, the use of a procedure involving chemical oxidation to accelerate the destruction of cyanide is often mandatory [4]. The most commonly used technology for cyanide destruction is the Inco cyanide remediation process and over 90 mines worldwide now use an $\mathrm{Inco} \mathrm{SO}_{2} /$ air detoxification circuit to convert cyanide to the much less toxic cyanate before waste is discharged to a tailings pond.

In cyanidation plants all around the world, the concentration of cyanide used to dissolve gold in ores is typically higher than the stoichiometric ratio, due to the solubility of other minerals. Free cyanide produces complexes with several metallic species, especially transition metals, which show a broad variation in both stability and solubility. Many common copper minerals are soluble in the dilute cyanide solution, typical of leach conditions found in the gold cyanidation process. Minerals such as azurite and malaquite, are fast leached and soluble in dilute cyanide solutions. Enargite and chalcopyrite leach more slowly but are sufficient soluble to cause ex- cessive cyanide loss and contamination of leach solutions with arsenic. Also, lead ores like galena and anglesite behave similarly toward cyanide, as the reactive effect of galena is largely due to the ease with which it oxidizes to sulphate. It is important to use low concentrations of alkali otherwise excessive amounts of alkaline plumbite will be formed, which will interact with the cyanide present to form basic insoluble lead cyanide, the main reactions are probably:

$$
\begin{aligned}
\mathrm{NaOH}+ & \mathrm{PbSO}_{4}=\mathrm{Na}_{2} \mathrm{PbSO}_{4}+\mathrm{Na}_{2} \mathrm{SO}_{4}+2 \mathrm{H}_{2} \mathrm{O} \\
& 3 \mathrm{Na}_{2} \mathrm{PbSO}_{2}+2 \mathrm{NaCN}+4 \mathrm{H}_{2} \mathrm{O} \\
= & \mathrm{Pb}(\mathrm{CN})_{2}+2 \mathrm{PbO}+8 \mathrm{NaOH}
\end{aligned}
$$

With low concentrations of alkaline, plumbite a less basic lead cyanide is formed. Therefore, hydrometallurgical treatment of these ores by cyaniding as a rule gives rise to a series of difficulties associated with increase in the cyanide and oxygen consumption rates, decrease in the dissolution rate of gold and silver, and in the cementation process this precipitate is of low quality, because the copper and especially lead are precipitated along with gold and silver, resulting in a higher consumption of zinc dust, fluxes in the smelting of the precipitate and shorter life for crucibles. In this regard a study is proposed to remove lead ions with hydroxyapatite and copper cyanide ions from barren solutions from the Merrill-Crowe process. This technology is based on inducing nucleated precipitation of copper and silver in a serpentine reactor, using sodium sulfide as the precipitator, and sulfuric acid for $\mathrm{pH}$ control.

\section{Cyanide and Copper Recovery Processes}

Sulphide precipitation of metals is a viable alternative process for copper recovery from the barren cyanide solutions because of the possible high degree of metal removal over a broad $\mathrm{pH}$ range [5]. For the application of copper and cyanide recovery after cyanidation, the key advantage of a sulphide precipitation process is the ability to operate in the barren solution to recover first the copper/silver and then the acidic conditions in the solution result in rapid release of free cyanide $\left(\mathrm{HCN}_{(\mathrm{gas})}\right)$ that is easily recoverable by volatilization at lowered $\mathrm{pH}$ value $[6,7]$.

If the cyanide is present in the barren solution after precipitation from the Merrill Crowe process as free cyanide $(\mathrm{pKa}=9.4)$, it is possible to convert $99 \%$ of the cyanide into $\mathrm{HCN}$ gas by lowering the $\mathrm{pH}$ of the solution to about 6 :

$$
\mathrm{CN}^{-}+\mathrm{H}^{-} \rightarrow \mathrm{HCN}_{(\mathrm{gas})}
$$

If, on the other hand, the cyanide is present as a metalcyanide complex, the $\mathrm{pH}$ must be reduced to more acidic 
values to break down the complex and produce $\mathrm{HCN}$ gas. For example, the weak zinc-cyanide complex $\left(\log \mathrm{B}_{4}=\right.$ 17.4) breaks down completely at about $\mathrm{pH} 5$, producing zinc sulfate as an aqueous soluble species, plus 4 moles of $\mathrm{HCN}$ gas:

$$
\mathrm{Zn}(\mathrm{CN})_{2}^{4-}+2 \mathrm{H}_{2} \mathrm{SO}_{4} \rightarrow \mathrm{ZnSO}_{4(\mathrm{~s})}+4 \mathrm{HCN}_{(\text {gas })}+\mathrm{SO}_{2}^{4-}
$$

The copper cyanide complex does not break down completely, even in strong acid solution, unless there is an oxidant present in the solution [7]. In the absence of oxidant, the copper tricyanide species (which is the most stable copper complex under normal cyanidation conditions: $\log \mathrm{B}_{3}=28$ ) decomposes to form a $\mathrm{CuCN}_{(\mathrm{s})}$ precipi- tate, plus 2 moles of $\mathrm{HCN}$ gas, at $\mathrm{pH}$ values less than 3 . Hence, $33 \%$ of potentially recoverable cyanide is lost to the precipitate:

$$
\mathrm{Cu}(\mathrm{CN})_{2}^{3-}+2 \mathrm{H}^{+} \rightarrow \mathrm{CuCN}_{(\mathrm{s})}+2 \mathrm{HCN}_{(\text {gas })}
$$

Also, in our case in the barren solution the ferrocyanide and cuprous cyanide are present and at $\mathrm{pH}=4$, produces double metal cyanide precipitate such as $\mathrm{Cu}_{2} \mathrm{Fe}$ $(\mathrm{CN})_{6}$ or $\mathrm{Cu}_{4} \mathrm{Fe}(\mathrm{CN})_{6}$ :

$$
\begin{aligned}
& 4 \mathrm{Cu}(\mathrm{CN})_{2}^{3-}+\mathrm{Fe}(\mathrm{CN})_{4}^{6-}+12 \mathrm{H}^{+} \rightarrow \\
& \mathrm{Cu}_{4} \mathrm{Fe}(\mathrm{CN})_{6(\mathrm{~s})}+12 \mathrm{HCN}_{(\mathrm{gas})}
\end{aligned}
$$

From the stoichiometry, it can be seen that the ferrocyanide molecule releases the third molecule of $\mathrm{CN}$ from the copper tricyanide complex, so the presence of ferrocyanide results in increased recovery of cyanide from the copper-cyanide species.

When thiocyanate is present, as is often the case when leaching sulphide-bearing ores, insoluble CuSCN may also be responsible for copper precipitation and in acid conditions, forming $\mathrm{HCN}$ gas, the following reaction shown this behavior:

$$
\mathrm{Cu}(\mathrm{CN})_{2}^{3-}+\mathrm{SCN}^{-}+3 \mathrm{H}^{+} \rightarrow \mathrm{CuSCN}_{(\mathrm{s})}+3 \mathrm{HCN}_{(\mathrm{gas})}
$$

Also, with the addition of sulphide ions $\left(\mathrm{Na}_{2} \mathrm{~S}\right)$ to the acidified cyanide solution results in the precipitation of cuprous sulphide (chalcocite), which is favored because of its extremely low solubility $\left(\mathrm{Ksp}=2.3 \times 10^{-48}\right)$ [7]. The following reaction takes place:

$$
\begin{aligned}
& 2 \mathrm{Cu}(\mathrm{CN})_{2}^{3-}+2 \mathrm{H}_{2} \mathrm{SO}_{4}+\mathrm{H}_{2} \mathrm{~S}_{(\text {gas })} \\
& \mathrm{Cu}_{2} \mathrm{~S}_{(\mathrm{s})}+6 \mathrm{HCN}_{(\text {gas })}+2 \mathrm{SO}_{4}^{2-}
\end{aligned}
$$

Stoichiometric usage of sulfide is approximately 0.25 grams $\mathrm{S}^{2-}$ per gram of copper, 0.44 grams NaHS per gram of copper or 0.61 grams $\mathrm{Na}_{2} \mathrm{~S}$ per gram of copper. However, the actual sulfide dosage required for nearcomplete copper precipitation is normally in excess of $200 \%$ due to additional ions in the barren solution. Also, in addition to precipitating copper, sulfide addition also results in the near-complete precipitation of silver, as shown in the following reaction.

$$
2 \mathrm{Ag}(\mathrm{CN})^{2-}+\mathrm{H}_{2} \mathrm{~S}_{(\text {gas })} \rightarrow \mathrm{Ag}_{2} \mathrm{~S}_{(\mathrm{s})}+4 \mathrm{HCN}_{(\mathrm{gas})}
$$

Based upon the reactions (10), acid conditions may cause the dissociation of the complexes, due to the formation of some copper precipitate and subsequent liberation of $\mathrm{HCN}$ by volatilization. Also accord with these reactions, up to $99 \%$ of copper could be recovered and $\mathrm{HCN}$ gas is stripping from the barren solutions and then adsorbed in an alkali solution of $\mathrm{NaOH}$. The simplified chemistry of the process is presented in the following reaction:

$$
\mathrm{HCN}_{(\text {gas })}+\mathrm{NaOH} \rightarrow \mathrm{NaCN}+\mathrm{H}_{2} \mathrm{O}
$$

The precipitate is a saleable copper product in its own right or can be blended with the arsenopirite flotation concentrate made in the flotation sulphide plant.

\subsection{Materials and Methods}

The experiments were carried out on barren cyanide solution generated by the filter press on the Merrill Crowe process. The pregnant solution came from the cyanidetion leach plant (500 ton/day), where the ores is a mixture of oxides and sulfides, with the range of copper being $0.04 \%$ to $0.25 \%$ copper as the norm; sample average contain: $1.7 \mathrm{~g} /$ ton $\mathrm{Au}, 100 \mathrm{~g} /$ ton $\mathrm{Ag}, 0.6 \% \mathrm{~Pb}, 0.61 \% \mathrm{Zn}$, $0.12 \% \mathrm{Cu}, 2.3 \% \mathrm{Fe}$ and $2 \%$ As. A wet screen analysis of the plant sample indicated that the granulometry was $80 \%$ minus $74 \mu \mathrm{m}$ (200 mesh). The leaching practice in the plant was: leach pulps containing $40 \%$ solids over a period of 72 hours leaching at $\mathrm{pH}=11.0, \mathrm{O}_{2}=5 \mathrm{ppm}$ and $2 \mathrm{~kg} /$ ton $\mathrm{NaCN}$; Leached residue: $0.20 \mathrm{~g} /$ ton $\mathrm{Au}$ and 0.18 $\mathrm{g} / \mathrm{ton} \mathrm{Ag}$.

Copper precipitation and cyanide regeneration experiments were performed to determine the effect of different process conditions on the solids of copper/silver sulphide produced by sulphide precipitation. Precipitation experiments were carried out in a 1 liter round-bottomed reaction vessel with ports for an overhead stirred, a gas sparger and a $\mathrm{pH}$ electrode. The $\mathrm{pH}$ meter is VWR 8005 Scientific and stirring motor with a glass impeller driven BDC 1850 CAFRAMO and cone size sedimentator $(1000 \mathrm{ml})$. The barren solutions used containing copper, silver, zinc and iron ions of varying concentration. The $\mathrm{pH}$ of the barren was adjusted to the required level with sulfuric acid and then mixture of $\mathrm{Na}_{2} \mathrm{~S} /$ water was added. In all precipitation experiments samples of the liquor and solid were taken at known times and then, solutions and solids from the process were then separated by filtration through cellulose filter paper. The sludge 
from the Precipitation was dried either in an oven or under vacuum at room temperature. Analysis of copper, silver, zinc, iron, and arsenic were performed by ICP/ Atomic Emission Spectrometry and free cyanide content was determined directly via titration, whereas the total cyanide was measured by means of titration after distillation. At the end of the experiment, $\mathrm{HCN}$ volatilization reached efficiencies above $95 \%$ and the capture of cyanide gas by $\mathrm{NaOH}(1 \mathrm{M})$ solution was almost $95 \%$.

\subsection{Results and Discussion}

The experiments were carried out at different $\mathrm{pH}$ under atmospheric pressure in glass reactor. In all the tests the barren initial solution from the Merrill-Crowe plant was from the same batch $(0.1 \mathrm{Ag}$ ppm, $184 \mathrm{Zn} \mathrm{ppm}, 636 \mathrm{Cu}$ $\mathrm{ppm}, 4 \mathrm{Fe} \mathrm{ppm})$. The following conditions were also fixed: temperature $25^{\circ} \mathrm{C}$; stirring speed $200 \mathrm{rpm} ; 0.5$ to 2 $\mathrm{g} / 1 \mathrm{Na}_{2} \mathrm{~S}$ and reaction time 90 seconds. The experimental results of the copper, silver, zinc and iron precipitation at different $\mathrm{pH}$ are presented in Table 1.

The results showed that $\mathrm{pH}$ had a great effect on copper cyanide removal efficiency and the optimum $\mathrm{pH}$ was about 3 to 4.0. At this $\mathrm{pH}$ value copper cyanide removal efficiency could be achieved above $99 \%$, when influent copper concentration ions were $636 \mathrm{ppm}$. Some black precipitates were observed in the solution samples of the pH 2 to 6 experiments; which suggested that there were copper, silver, arsenic, zinc and iron as sulphide.

The size, EDX and morphology of the solids in experiment $\mathrm{pH}$ are also shown in Figure $\mathbf{1}$ by SEM and EDX analysis.

The solids in the precipitates are spherical and approximately $100 \mathrm{~nm}$ in diameter. Figure 1 shows chemical composition of solid product as determined by EDX, which shows the presence of copper, sulphur, zinc and iron in the sulphide particle.

The SEM figure confirms the excellent crystallinity of synthetic covellite $(\mathrm{CuS})$ formed during sulphide precipitation process. The EDX pattern of the precipitate at different $\mathrm{pH}$ values is shown in Table 2.

The results of Table 2 indicated that the $\mathrm{pH}=3$ value is the best condition to have the sulphide precipitation of copper.

\subsection{Industrial Application}

In base on the experimental evidence obtained with the sulphide precipitation study for copper and cyanide removal from the barren solution after the Merrill-Crowe process. This process has been installed on a mine site at full scale. A simplified process flow diagram in which uses sodium sulphide $\left(\mathrm{Na}_{2} \mathrm{~S}\right)$ such as sulphide ions, to precipitate copper and silver and convert cyanide to $\mathrm{HCN}$ gas, under acid conditions (pH 3 to 4 ) is shown in Figure 2.

The SERPENTINE system is a viable technology for the recovery of copper, silver and subsequent recovery of $\mathrm{HCN}$ gas by scrubbing in $\mathrm{NaOH}$. Barren solution is currently fed to the SERPENTIN at 10 to 15 liters/second at a $\mathrm{pH}$ 11. At this flow rate, the precipitate of calcium sulphate (scale) would not occur. In five continuous working days the treated solution exits the circuit at a $\mathrm{pH}$ of 3 , carrying about 0 to $10 \mathrm{ppm}$ of copper and $200 \mathrm{ppm}$ cyanide and is pumped to two neutralizing $(\mathrm{pH} \mathrm{7)}$ tanks. The operation of the SERPENTIN produce high grade copper sulphide precipitate in the range of $40 \%$ to $55 \%$ of $\mathrm{Cu}$ with $130 \mathrm{gr} / \mathrm{ton} \mathrm{Ag}$ and recoveries of cyanide of $80 \%$.

Table 1. Results of copper, silver, zinc and iron sulphide precipitates at different $\mathrm{pHs}$ and concentrations of $\mathrm{Na}_{2} \mathrm{~S}$.

\begin{tabular}{|c|c|c|c|c|c|c|}
\hline & Ag & Zn & $\mathrm{Cu}$ & $\mathrm{Fe}$ & $\mathrm{Na}_{2} \mathrm{~S}$ (grs) & pH \\
\hline $\begin{array}{c}\text { Feed barren } \\
\text { Solution (ppm) }\end{array}$ & 0.1 & 184 & 636 & 4 & 0 & 10.95 \\
\hline Solution 1 (ppm) & 0 & 73 & 389 & 2 & 1.0 & 6 \\
\hline Precipitate $1,(\%)$ & 124 & 17.60 & 44.90 & 1.2 & - & - \\
\hline Solution 2 (ppm) & 0 & 93 & 420 & 2 & 0.5 & 6.0 \\
\hline Precipitate 2, (\%) & 121 & 21.40 & 40.70 & 1.0 & - & - \\
\hline Solution 3 (ppm) & 0 & 22 & 31 & 2 & 1.0 & 5.5 \\
\hline Precipitate $3,(\%)$ & 114 & 11.90 & 51.70 & 1.0 & - & - \\
\hline Solution 4 (ppm) & 0 & 8 & 0 & 0 & 1.0 & 5.0 \\
\hline Precipitate $4,(\%)$ & 119 & 13.4 & 51.27 & 1.0 & - & - \\
\hline Solution 5 (ppm) & 0 & 32 & 0 & 0 & 1.0 & 4.5 \\
\hline Precipitate $5,(\%)$ & 138 & 9.92 & 56.34 & 0.9 & - & - \\
\hline Solution 6 (ppm) & 0 & 54 & 0 & 0 & 1.0 & 4 \\
\hline Precipitate $6,(\%)$ & 118 & 1.49 & 62.68 & 1.1 & - & - \\
\hline Solution 7 (ppm) & 0 & 40 & 0 & 0 & 1.0 & 3.0 \\
\hline Precipitate $7,(\%)$ & 129 & 9.53 & 62.24 & 1.1 & - & - \\
\hline Solution 8 (ppm) & 0 & 134 & 0 & 0 & 1.0 & 2.5 \\
\hline Precipitate $8,(\%)$ & 106 & 11.24 & 60.5 & 0.9 & - & - \\
\hline
\end{tabular}



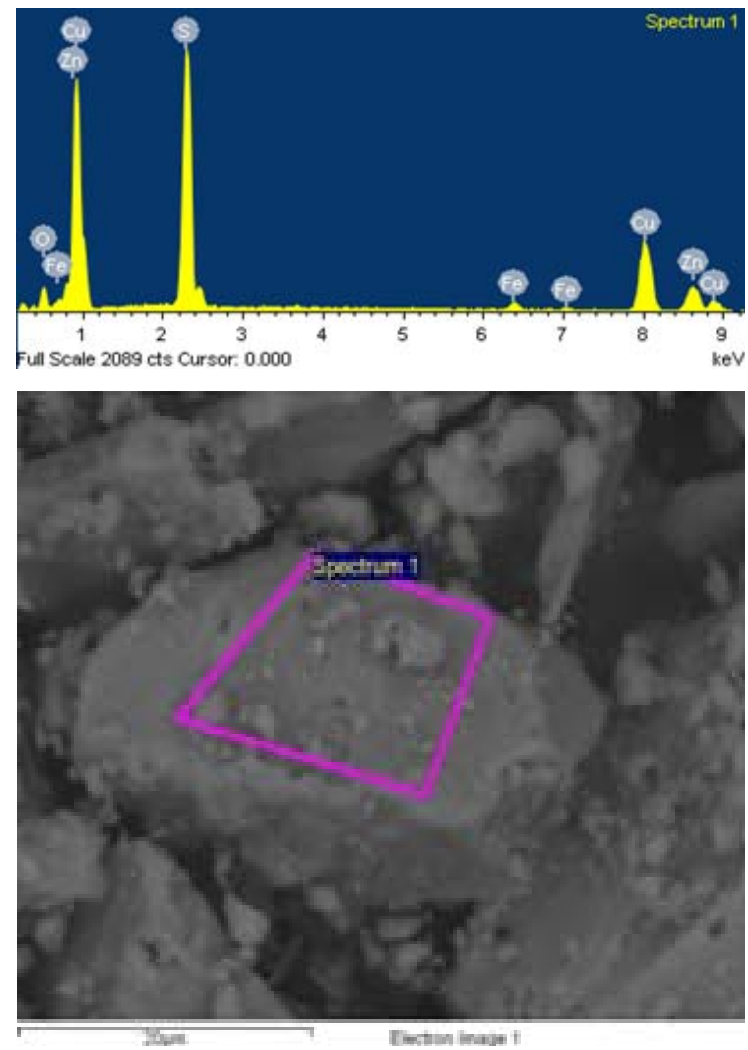

Figure 1. Shows the EDX and morphology of covellite (CuS).

\section{Removal of Lead Hydroxides Complexes by Using Hydroxyapatite Powder}

There are several methods for lead ions removal from waste-water: effluent limitations; chemical precipitation (hydroxide precipitation, sulfide precipitation, carbonate precipitation, and so on); physical treatment (ion exchange, adsorption and foam flotation). In particular, treatment of processes for lead removal from waste water must be selected to remove the existing form of lead ions. In general, lead is precipitated or otherwise attached to an insoluble form through adsorption or ion exchange. Treatment processes for lead removal from water and waste water through adsorption or ion exchange were recently studied.

Increasingly stringent in the precipitation and refining plant on the purity of the Dore has created a growing interest in the development of a novel process for removal lead hydroxides from the pregnant cyanide solution before the cementation in the filter press. Treatment processes for lead hydroxides removal from cyanide liquors through adsorption on animal powder bone $\left(\mathrm{Ca}_{10}\right.$ $\left.\left(\mathrm{PO}_{4}\right)_{6}(\mathrm{OH})_{2}\right)$ is an economical and natural source of phosphate, which has a high removal capacity for divalent heavy metal ions [8], and, in the present study, we performed a new approach for cleaning the precious precipitate of plumbite ions.

Table 2. Chemical composition determined by EDX for different pH values.

\begin{tabular}{|c|c|c|c|c|c|c|}
\hline \multirow{2}{*}{ Element } & \multicolumn{2}{|c|}{$\mathrm{pH}=2$} & \multicolumn{2}{|c|}{$\mathrm{pH}=3$} & \multicolumn{2}{|c|}{$\mathrm{pH}=4$} \\
\hline & Weight $\%$ & Atomic $\%$ & Weight $\%$ & Atomic \% & Weight \% & Atomic $\%$ \\
\hline O K & 7.69 & 20.37 & 9.64 & 24.35 & 7.73 & 20.03 \\
\hline $\mathrm{Na} \mathrm{K}$ & & & & & 2.51 & 4.52 \\
\hline S K & 27.85 & 36.80 & 29.02 & 36.57 & 26.44 & 34.18 \\
\hline $\mathrm{Ca} \mathrm{K}$ & & & 0.60 & 0.61 & 0.45 & 0.46 \\
\hline $\mathrm{Fe} \mathrm{K}$ & 2.06 & 1.56 & 1.96 & 1.42 & 1.90 & 1.41 \\
\hline Totals & 100.00 & & 100.00 & & 100.00 & \\
\hline
\end{tabular}

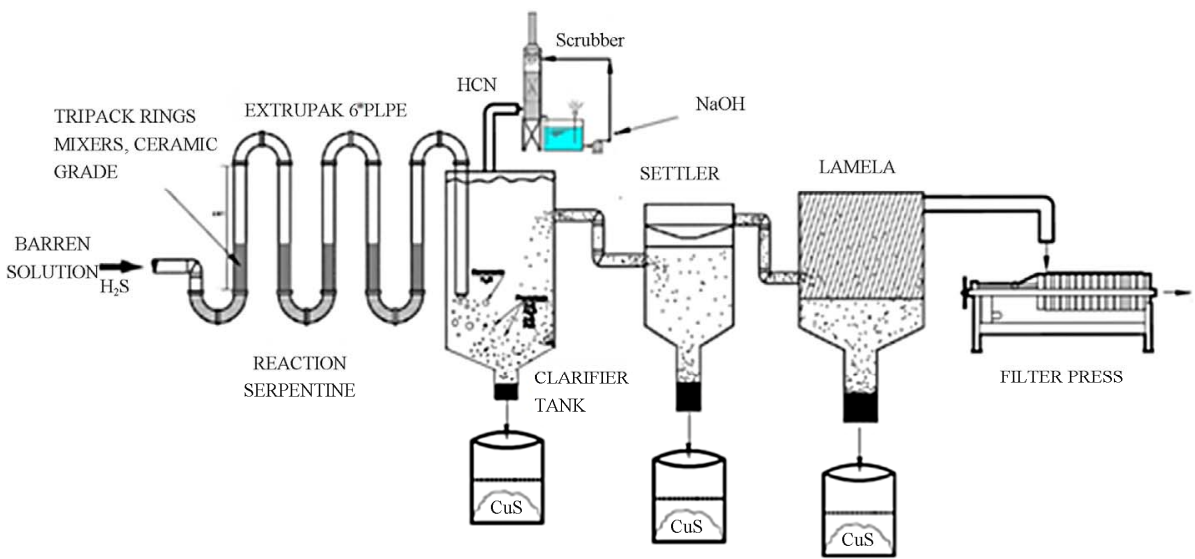

Figure 2. A schematic diagram of the SERPENTIN INDUSTRIAL PLANT. 


\subsection{Material and Methods}

Natural bone contain high amount of $\mathrm{Ca}$ and $\mathrm{P}$ in the form of hydroxyapatite and thus represent a potential resource with possible application in the remediation contamination of the precious precipitate with lead. It was used as the source for the adsorbent. The bones was supplied by a company involved in commercial meat by products, it was chopped into small pieces, washing with lime $\left(\mathrm{Ca}(\mathrm{OH})_{2}\right)$ and dried in sunlight until the moisture was partially evaporated, and further dried in the hot air oven at $60^{\circ} \mathrm{C}$ for $24 \mathrm{~h}$. It was then sieved and particles ranging from 125 to $180 \mu \mathrm{m}$ were used for the study. The sieved powder bones were then used in the sorption experiments as described in the following sections. Physical and chemical characteristics of the bones are summarized in the Table 3 .

\subsection{Batch Adsorption Experiments}

A stock solution of $20 \mathrm{mg} / \mathrm{dm}^{3}$ lead (II) was prepared with the pregnant liquor of the cyanidation plant. Each of the batch adsorption tests were carried out by mixing 0.1 to 0.6 grams of cow bone powder with one liter of lead complexes hydroxides solution for a time of 30 minutes. The adsorption process was carried out in a $1000 \mathrm{ml}$ reactor, stirred at $300 \mathrm{rpm}$.

The adsorbent was separated using a $0.45 \mu \mathrm{m}$ cellulose acetate filter at different time intervals. Samples of remaining solutions were analyzed for $\mathrm{Pb}$ concentrations by atomic absorption spectroscopy. The quality control of the solution analysis was achieved by using appropriate blank control.

\subsection{Results and Discussion}

Figure 3 shows the effect contact time on uptake of lead adsorbed from cyanide liquors by the use of different amounts of bone powder. It is apparent that the uptake of lead ions by the bone increased by increasing the amount of bone powder and the time affect of adsorption of lead on the bone powder reaches equilibrium state after 30 minutes.

\subsection{Characterization of Clean Bone and Bone with 20 ppm Pb, High Resolution X-ray Micro Tomography (HRXMT) Scans}

Two bone samples, namely clean (50 - 70) and bone with

Table 3. Physical and chemical characteristics of bone.

\begin{tabular}{cc}
\hline Parameter & Value \\
\hline Moisture $(\%)$ & Nil \\
Surface area $\left(\mathrm{m}^{2} / \mathrm{gr}\right)$ & 0.344 \\
Particle size $(\mu \mathrm{m})$ & $147-417$ \\
Water-soluble matter $(\%)$ & Nil \\
Apparent density $\left(\mathrm{g} / \mathrm{cm}^{3}\right)$ & 0.20 \\
\hline
\end{tabular}

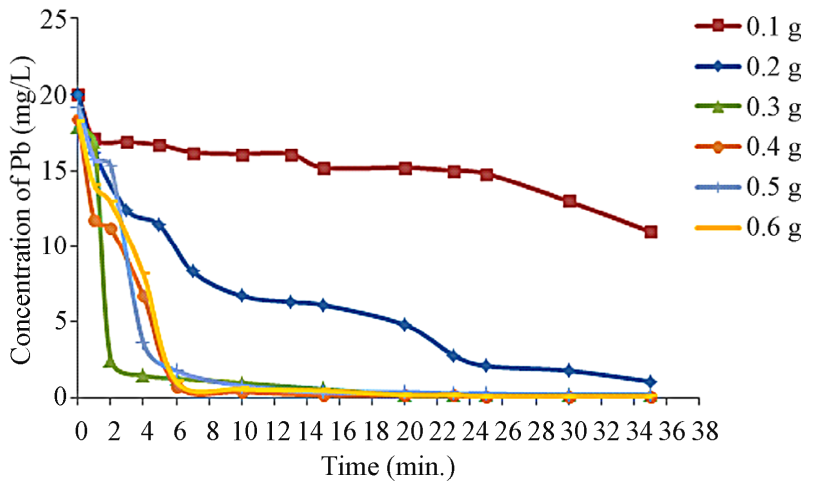

Figure 3. Effect of contact time on uptake of lead adsorbed from cyanide liquors by the use of different amounts of bone powder.

$20 \mathrm{ppm} \mathrm{Pb}$, were scanned using the HRXMT facility. Operation parameters for the HRXMT scans are summarized as follow: $60 \mathrm{KV}, 4 \times$ lens, 10 second exposure time, $150 \mu \mathrm{m}$ glass filter, 1000 projected views, $360^{\circ}$ rotation, and 5.04 micron reconstructed resolution.

Figure 4 presents the 2D slice and the zoom image for bone sample with $20 \mathrm{ppm} \mathrm{Pb}$. The lead is clearly on the surface regions of the bone particles. The 3D image consists of $992 \times 1013 \times 992$. The size of each voxel is 5.04 $\times 5.04 \times 5.04 \mu \mathrm{m}$. Triplanar and 9 sliced from 288 to 296 along the Z-direction.

This image show that the bone samples by micro CT not much internal surface area is found at this CT resolution as might be expected from the low BET surface area. Figure 4 best illustrates that lead adsorption occurs on the external particle surfaces.

\section{Conclusion}

The advantages of the SERPENTIN PLANT include high precipitation rate of copper and silver (99\%), compact treatment facility, relatively low operation cost, the precipitate is a saleable copper/silver product, the main advantage of using the SERPENTIN is the low energy that is used and finally, the industrial operation of the SERPENTIN produces high grade copper sulphide precipitate in the range of $40 \%$ to $55 \%$ of $\mathrm{Cu}$ with 130 $\mathrm{gr} / \mathrm{ton} \mathrm{Ag}$ and recoveries of cyanide of $80 \%$. Also, from this study we can conclude that the bone powder in an excellent adsorbed for lead hydroxides ions. The results show that the elimination of lead ions from the pregnant reach solution with natural hydroxyapatite (from bones) the recovery was $99 \%$. Finally, the precipitate improves the quality $500 \%$.

\section{Acknowledgements}

The authors wish to acknowledge support of this project to Minera William in Mexico, the National Council of 


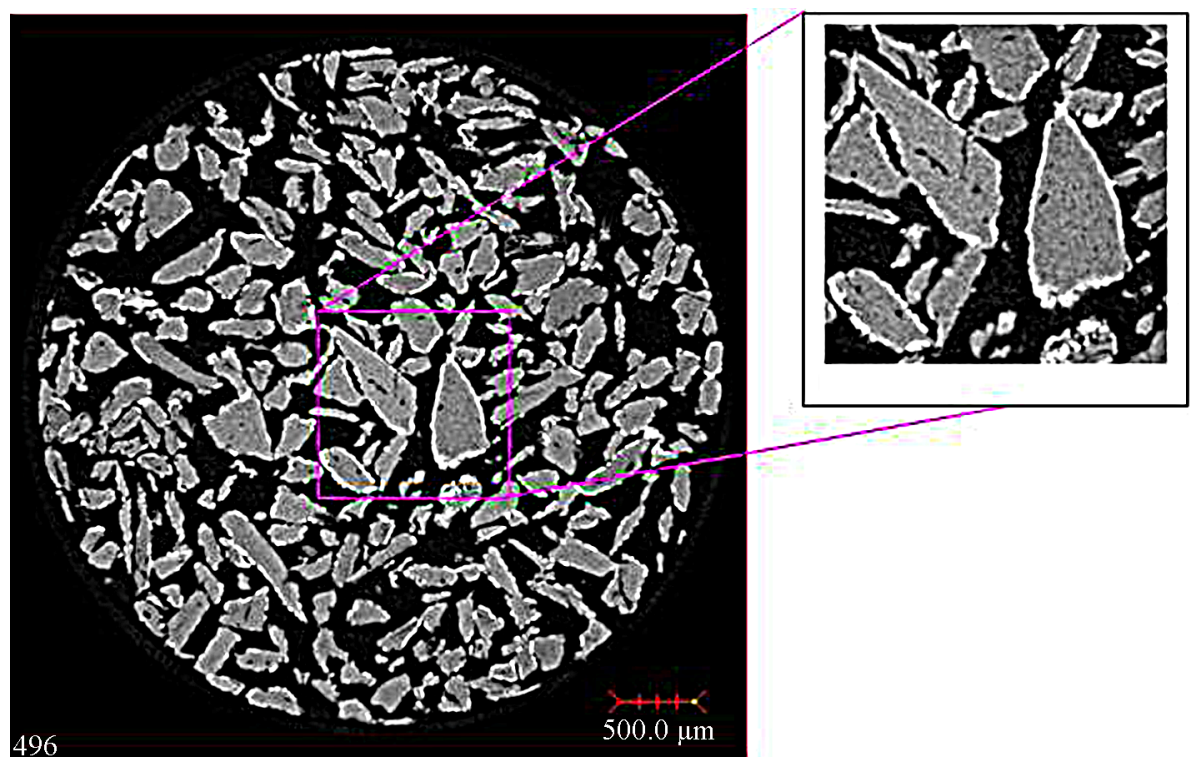

Figure 4. 2D sliced image of bone sample with $20 \mathrm{ppm} \mathrm{Pb.}$

Science and Technology (CONACYT) and to Dirección General de Educación Superior Tecnológica (DGEST) from Mexico.

\section{REFERENCES}

[1] F. Habashi, "One Hundred Years of Cyanidation Historical Note," CIM Bulletin, Vol. 30, No. 905, 1987, pp. 108-114.

[2] J. R. Parga, J. L. Valenzuela and F. Cepeda, "Pressure Cyanide Leaching for Precious Metals Recovery," Journal of Metals, Vol. 10, 2007, pp. 43-47.

[3] J. R. Parga, H. M. Casillas, V. Vazquez and J. L. Valenzuela, "Cyanide Detoxification of Mining Wastewaters with $\mathrm{TiO}_{2}$ Nanoparticles and Its Recovery by Electrocoagulation," Chemical Engineering and Technology, Vol. 32, No. 12, 2009, pp. 1901-1908. doi:10.1002/ceat.200900177

[4] A. E. Lewis, "Review of Metal Sulphide Precipitation,"
Hydrometallurgy, Vol. 104, 2010, pp. 222-234. doi:10.1016/j.hydromet.2010.06.010

[5] C. W. Lawr, "Cyanide Regeneration as Practiced by Compañia Beneficiadora de Pachuca," Technical Publication AIME, Vol. 6, No. 208, 1929, pp. 1-37.

[6] D. M. Muir, "A Review of the Selective Leaching of Gold from Oxidized Copper-Gold Ores with AmmoniaCyanide and New Insights for Plant Control and Operation," Minerals Engineering, Vol. 24, No. 6, 2011, pp. 576-582. doi:10.1016/j.mineng.2010.08.022

[7] M. D. Adams and R. Lawrence, "Biogenic Sulphide for Cyanide Recycle and Copper Recovery in Gold-Copper Ore Processing," Proceedings of the Precious Metals, Brisbane, 31 August 2007, pp. 1-17.

[8] S. Woodgate and A. Dybowska, "An Evaluation of the Reactivity of Synthetic and Natural Apatites in the Presence of Aqueous Metals," The Science of Total Environment, Vol. 407, No. 8, 2009, pp. 2953-2965. 